\title{
NILAI RETENSI NITROGEN DAN ENERGI METABOLIS RANSUM MENGGUNAKAN DAUN MURBEI (Morus alba) SEGAR PADA BROILER
}

\author{
Zebedeus Dady*, J. S. Mandey, M. R. Imbar, M. N. Regar \\ Fakultas Peternakan Universitas Sam Ratulangi Manado 95115
}

\begin{abstract}
ABSTRAK
Penelitian tentang penggunaan murbey (Morus alba) segar dalam ransum broiler telah dilaksanakan untuk mengetahui pengaruhnya terhadap nilai retensi nitrogen (NR) dan nilai energi metabolis terkoreksi nitrogen (AMEn) ransum. Penelitian menggunakan 20 ekor broiler CP 707 umur 6 minggu yang terdiri dari 7 hari pendahuluan dan 3 hari pengumpulan data. Rancangan yang digunakan adalah rancangan acak lengkap (RAL) yang terdiri 4 perlakuan dan lima ulangan. Perlakuan tersebut adalah daun murbei dengan beberapa tingkat pemberian dalam ransum, yaitu: $\mathrm{R} 0=0 \%, \mathrm{R} 1=2 \%, \mathrm{R} 2=$ $4 \%$ dan $\mathrm{R} 3=6 \%$, yang disubstitusi pada ransum dasar. Variabel yang diukur guna melihat respons biologis broiler terhadap daun murbei adalah nilai retensi nitrogen (NR) dan nilai energi metabolis terkoreksi nitrogen (AMEn). Hasil analisis keragaman menunjukkan bahwa perlakuan berbeda nyata $(\mathrm{P}<0,05)$ terhadap nilai $\mathrm{NR}$ dan berbeda sangat nyata $(\mathrm{P}<0.01)$ terhadap nilai AMEn. Hasil uji lanjut BNJ untuk nilai NR menunjukkan bahwa perlakuan R0 $(89,81 \%)$ berbeda nyata $(\mathrm{P}<0,05)$ dengan perlakuan R2 $(84,51 \%)$ dan R3 (84,09\%). Untuk perlakuan R0 dan R1 $(85,97 \%)$ tidak berbeda nyata, sama halnya dengan R1, R2 dan R3. Nilai AMEn menunjukkan bahwa perlakuan R0 (4023,82 $\mathrm{Kkal} / \mathrm{kg})$ berbeda nyata $(\mathrm{P}<0.05)$ dengan perlakuan R1 (3517,80 Kkal/kg), R2 (3451,73 $\mathrm{Kkal} / \mathrm{kg}) \quad$ dan $\mathrm{R} 3 \quad(3360,90 \quad \mathrm{Kkal} / \mathrm{kg})$. Sementara antara perlakuan R1, R2 dan R3 tidak terdapat perbedaan. Berdasarkan hasil
\end{abstract}

\footnotetext{
*Korespondensi (corresponding author):

Email: dadyzebedeus@yahoo.co.id
}

penelitian ini dapat disimpulkan bahwa daun murbei segar dapat digunakan sebagai bahan pakan alternatif dalam ransum broiler sampai $6 \%$ dilihat dari nilai retensi nitrogen dan energi metabolis.

Kata kunci: broiler, daun murbei, retensi nitrogen dan energi metabolis terkoreksi nitrogen

ABSTRACT
NITROGEN RETENTION AND
METABOLIZABLE ENERGY OF
MULBERRY (Morus alba) FRESH LEAVES
IN DIET OF BROILERS. The study was
determine to evaluate the effect of Mulberry
(Morus alba) fresh leaves in diet on nitrogen
retention and metabolizable energy corrected
for nitrogen of broilers. A total of 20 birds at
age of 6 weeks old were used for 7 days of
preliminary period and 3 days of data
collection period using a completely
randomized design with four treatments and
five replications. The dietary treatment was
including levels of $0,2,4$, and $6 \%$ of fressh
mulberry leaves in the diets. The variables
were nitrogen retention (NR) and
metabolizable energy corrected for nitrogen
(AMEn). Results showed that there were
significant differences (P $<0.05$ ) among
treatments for NR and highly significant
differences (P $<0.01$ among treatments for
AMEn. Analysis of variance for NR showed
that there was no significant difference
between R0 $(89.81 \%)$ and R1 (85.97\%) of
diets. Similarly, there was no significant
difference between R1 (85.97), R2 ( $84.51 \%$ )
and R3 (84.09\%) of diets. The values of


AMEn showed that R0 diet had significant difference with those of R1 (3517.80 $\mathrm{Kcal} / \mathrm{Kg}), \quad \mathrm{R} 2 \quad(3451.73 \mathrm{Kcal} / \mathrm{Kg})$ and R3 (3360.90 Kcal/Kg). However, between R1, R2, and R3 had no significant differences. The results suggested the experiments of mulberry fresh leaves in level up to $6 \%$ can be used as an alternatives feedstuff of broiler diet based on nitrogen retention and metabolizable energy corrected for nitrogen.

Key words: broiler, murbei leaves, nitrogen retention and metabolic energy corrected nitrogen

\section{PENDAHULUAN}

Daun murbei (Morus alba) merupakan salah satu bahan pakan alternatif yang selama ini digunakan sebagai pakan ulat sutera, dan juga memiliki potensi sebagai bahan pakan unggas, karena mengandung zat-zat makanan, yaitu : kadar air $(68,89 \%)$, abu $(9,83 \%)$, serat kasar $(10,21 \%)$, lemak kasar $(4,10 \%)$, bahan kering $(30,11 \%), \mathrm{Ca}$ $(1,71 \%), \quad \mathrm{P} \quad(0,36 \%)$, protein kasar $(22,95 \%)$ BETN $(53,26 \%)$,dan energi bruto (4502 kkal/kg) (Nunuh dan Andikarya, 2006).

Daun murbei dapat digunakan sebagai bahan pakan alternatif sumber protein nabati di dalam pakan, serta sumber kalsium dan fosfor, tetapi penggunaannya dibatasi mengingat kemampuan ayam yang terbatas dalam mencerna serat kasar. Disamping itu, daun murbei mengandung senyawa deoxynojirimycin (DNJ) yang dapat menghambat hidrolisis karbohidrat (glukosa, maltosa, sukrosa, dan pati) (Oku et al., 2006; Rahmi, 2009).

Penentuan kecernaan dilakukan untuk mengetahui seberapa besar zat-zat makanan yang dapat diserap untuk kebutuhan pokok, pertumbuhan, dan produksi. Kecernaan adalah banyaknya atau jumlah zat-zat makanan yang ditahan atau diserap oleh tubuh, yang dipengaruhi oleh tingkat pemberian pakan, spesies hewan, suhu, laju perjalanan makanan melalui alat pencernaan, bentuk fisik bahan pakan, komposisi ransum, kandungan lignin bahan pakan, defisiensi zat makanan, pengolahan bahan pakan, pengaruh gabungan bahan pakan, dan gangguan saluran pencernaan meskipun tidak konsisten (Tillman et al., 1998).

Kecernaan energi metabolis dan retensi nitrogen merupakan variabel untuk mengetahui kandungan energi dan kualitas protein pakan. Hal tersebut dapat dilakukan dengan mengukur konsumsi energi dan nitrogen dikurangi pengeluaran energi dan nitrogen dalam feses dan urin, sehingga diketahui jumlah energi dan nitrogen yang tertinggal dalam tubuh (Scott et al., 1982). Penelitian tentang kecernaan daun murbei sudah pernah dilakukan, tetapi setelah proses fermentasi. 
Penelitian kecernaan pakan mengandung daun murbei segar belum pernah dilakukan, sehingga berdasarkan pemikiran tersebut maka telah dilakukan penelitian untuk mengukur nilai retensi nitrogen dan energi metabolis ransum yang menggunakan daun murbei (morus alba) segar pada broiler.

Penelitian ini bertujuan untuk mengetahui nilai energi metabolis dan retensi nitrogen ransum yang menggunakan daun murbei (Morus alba) segar pada broiler. Selain itu hasil penelitian ini diharapkan menjadi acuan informasi ilmiah khususnya tentang penggunaan daun murbei segar dalam ransum broiler

\section{MATERI DAN METODE PENELITIAN}

Penelitian ini telah di lakukan di Kandang Fakultas Peternakan Universitas Sam Ratulangi Manado, sejak tanggal 7 Mei 2015 sampai 17 Mei 2015 yang terdiri dari 7 hari pendahuluan dan 3 hari pengambilan data. Penelitian ini menggunakan 20 ekor broiler strain CP 707 berumur 6 minggu dengan rataan berat badan $\pm 1550 \mathrm{Kg}$.

Kandang yang digunakan adalah kandang energi metabolis berukuran 40x30x30 cm, terdiri dari 20 unit kandang yang dilengkapi dengan tempat makan dan minum. Perlengkapan lain yang digunakan adalah timbangan digital Ohaus (untuk menimbang ayam, ransum dan ekskreta), wadah penampung ekskreta, tabung penyemprot, aluminium foil, pengaduk dan oven untuk mengeringkan ekskreta. Bahan kimia yang digunakan selama percobaan adalah asam borat $5 \%$.

Bahan pakan penyusun ransum terdiri dari jagung kuning (58\%), dedak halus (5\%), tepung ikan (15\%), tepung kedele (11\%), bungkil kelapa (9\%), minyak kelapa (1\%) dan mineral mix (1\%). Komposisi zat makanan dan energi metabolis ransum dasar dan daun murbei dapat dilihat pada Tabel 1 dan susunan ransum perlakuan serta komposisi zat-zat makanan dan energi metabolis dapat dilihat pada Tabel 2.

Penelitian ini menggunakan Rancangan Acak Lengkap (RAL) menurut petunjuk Steel and Torrie (1995), yang terdiri dari 4 perlakuan dan 5 ulangan. Data yang diperoleh dianalisis, dan bila terdapat perbedaan dilanjutkan dengan uji lanjut Beda Nyata Jujur (BNJ).

Variabel yang diukur yaitu retensi nitrogen dan energi metabolis menurut petunjuk Zarei (2006) dengan menggunakan rumus : 
Tabel 1. Komposisi Zat Makanan dan Energi Bruto Ransum Dasar dan Daun Murbei (100\% BK)

\begin{tabular}{lcccc}
\hline \multirow{2}{*}{$\begin{array}{c}\text { Zat Makanan dan } \\
\text { Energi }\end{array}$} & $\begin{array}{c}\text { Ransum } \\
\text { Dasar } *\end{array}$ & Segar & $\begin{array}{l}\text { Berat } \\
\text { Kering** }\end{array}$ & Bahan Kering \\
\cline { 3 - 5 } & & & - & - \\
\hline Kadar Air (\%) & - & 34,2 & 93,49 & - \\
Bahan Kering (\%) & 20,58 & 7,09 & 19,06 & 20,39 \\
Protein Kasar (\%) & 5,66 & 0,31 & 0,82 & 0,88 \\
Lemak Kasar (\%) & 60,29 & 15,43 & 41,44 & 44,33 \\
Beta-N & 7,78 & 5,25 & 16,79 & 17,95 \\
Serat Kasar (\%) & 1,77 & 1,05 & 2,83 & 3,03 \\
Ca $(\%)$ & 0,41 & 0,15 & 0,41 & 0,44 \\
P (\%) & 5,64 & 5,83 & 15,68 & 16,77 \\
Abu (\%) & 4961,93 & 1662,56 & 4359 & 4662,53 \\
EB (Kkal/kg) & & &
\end{tabular}

Keterangan : *) Hasil Analisa Laboratorium Ilmu dan Teknologi Pakan, Instititut Pertanian Bogor (2015)

**) Mandey dan Rahasia,. 2015 (Belum dipublikasi)

Tabel 2. Susunan Ransum Perlakuan Serta Komposisi Zat-zat Makanan dan Energi Bruto Ransum Perlakuan

\begin{tabular}{lrrrr}
\hline & $\mathrm{R}_{0}$ & $\mathrm{R}_{1}$ & $\mathrm{R}_{2}$ & $\mathrm{R}_{3}$ \\
\hline Ransum Basal (\%) & 100 & 98 & 96 & 94 \\
Daun Murbei Segar (\%) & - & 2 & 4 & 6 \\
\hline \multicolumn{1}{c}{ Total } & $\mathbf{1 0 0}$ & $\mathbf{1 0 0}$ & $\mathbf{1 0 0}$ & $\mathbf{1 0 0}$ \\
\hline \multicolumn{1}{c}{ Zat-Zat Makanan *) } & & & \\
\hline Protein (\%) & 20,58 & 20,58 & 20,57 & 20,57 \\
Serat Kasar (\%) & 7,78 & 7,99 & 8,19 & 8,39 \\
Lemak (\%) & 5,66 & 5,56 & 5,46 & 5,37 \\
Beta-N & 60,29 & 59,97 & 59,65 & 59,33 \\
Ca (\%) & 1,77 & 1,79 & 1,82 & 1,84 \\
P (\%) & 0,41 & 0,41 & 0,42 & 0,42 \\
Abu (\%) & 5,64 & 5,87 & 6,09 & 6,31 \\
EB (Kkal/kg) & 4961,93 & 4955,94 & 4949,95 & 4943,96
\end{tabular}

*) Dihitung berdasarkan Tabel 1 
1. Retensi Nitrogen (NR)

$\mathrm{NR}(\%)=\frac{(\mathrm{F} i \times \mathrm{N} f)-(\mathrm{E} \times \mathrm{N} e)}{(\mathrm{F} i \times \mathrm{N} f)} \times 100 \%$

Keterangan:

NR : Retensi Nitrogen (\%)

$\mathrm{N} f$ :Nitrogen Pakan (\%)

$\mathrm{Ne}$ : Nitrogen Ekskreta (\%)

$\mathrm{Fi}$ : Pakan yang dikonsumsi (g)

E : Jumlah Ekskreta (g)

2. Energi Metabolis (AMEn)

AMEn

$=\frac{(\mathrm{Fi} \times \mathrm{GE} f)-(\mathrm{E} \times \mathrm{GE} e)-(\mathrm{NR} \times \mathrm{K})}{\mathrm{F} i}$

Keterangan :

AMEn : Energi metabolis semu yang dikoreksi dengan retensi nitrogen $(\mathrm{kkal} / \mathrm{kg})$

$\mathrm{Fi}$ : Banyaknya pakan yang dikonsumsi

(g)

E : Jumlah Ekskreta (g)

GE $f$ : Energi Bruto pakan (kkal/kg)

Gee : Energi Bruto ekskreta (kkal/kg)

NR : Retensi Nitrogen $(\mathrm{g})$ $\mathrm{NR}=(\mathrm{F} i \times \mathrm{N} f)-(\mathrm{E} \times \mathrm{N} e)$

$\mathrm{K}$ : Konstanta koreksi untuk nilai energI nitrogen yang diretensi

$(8.73 \mathrm{Kkal} / \mathrm{kg}$ untuk setiap gram nitrogen)

\section{HASIL DAN PEMBAHASAN}

Rataan nilai retensi nitrogen (NR) dan nilai energi metabolis terkoreksi nitrogen (AMEn) ransum menggunakan daun murbei (Morus alba) segar pada broiler disajikan pada Tabel 3.

\section{Pengaruh Perlakuan Terhadap Nilai Retensi Nitrogen Ransum Broiler}

Nilai retensi nitrogen (NR) diperoleh dari selisih antara nitrogen yang dikonsumsi broiler dikurangi dengan nilai nitrogen dalam ekskreta.

Rataan nilai retensi nitrogen ransum menggunakan daun murbei (Morus alba) segar dalam penelitian ini berkisar antara 84,09\% - 89,91\% (Tabel 3). Nilai retensi nitrogen berturut-turut dari yang tertinggi diperoleh pada perlakuan R0 $(89,91 \%)$ selanjutnya diikuti oleh R1 (85,97\%), R2 ( 84,51\%), dan R3 (84,09\%).

Tabel 3. Rataan Nilai Retensi Nitrogen (NR) dan Energi Metabolis Terkoreksi Nitrogen (AMEn) Ransum Menggunakan Daun Murbei Segar (Morus alba) Pada Broiler

\begin{tabular}{lcccc}
\hline \multirow{2}{*}{ Parameter } & \multicolumn{4}{c}{ Perlakuan } \\
\cline { 2 - 5 } & R0 & R1 & R2 & R3 \\
\hline Nilai NR (\%) & $89,81^{\mathrm{a}}$ & $85,97^{\mathrm{ab}}$ & $84,51^{\mathrm{b}}$ & $84,09^{\mathrm{b}}$ \\
Nilai AMEn (Kkal/kg) & $4023,82^{\mathrm{a}}$ & $3517,80^{\mathrm{b}}$ & $3451,73^{\mathrm{b}}$ & $3360,90^{\mathrm{b}}$ \\
\hline
\end{tabular}

Keterangan : Superskrip yang berbeda pada baris yang sama menunjukkan adanya perbedaan yang nyata $(\mathrm{P}<0,05)$. 
Berdasarkan hasil analisis keragaman (ANOVA), penggunaan daun murbei segar dalam ransum broiler memberikan pengaruh berbeda nyata $(\mathrm{P}<0.05)$ terhadap retensi nitrogen. Hasil uji BNJ menunjukkan perlakuan R0 berbeda nyata dengan perlakuan R2 dan perlakuan R3. Untuk perlakuan R0 dan perlakuan R1 tidak terdapat perbedaan, sama halnya dengan perlakuan R1, R2 dan R3

Menurut Wahju (2004), bahwa efisiensi protein yang diretensi oleh broiler adalah $67 \%$ dari protein ransum yang dikonsumsi. Jadi hanya $67 \%$ yang diretensi untuk pertumbuhan jaringan per hari, penggantian bulu dan penggantian nitrogen endogen yang hilang. Nitrogen yang diretensi ini mengambarkan efesiensi penggunaan protein pada broiler. Nilai retensi nitrogen yang diperoleh dari penelitian ini $(84,09 \%-89,91 \%)$ lebih tinggi dari $67 \%$. Lebih lanjut dikatakan bahwa, peningkatan retensi nitrogen tersebut dipengaruhi oleh meningkatnya kecernaan nitrogen. Meningkatnya nitrogen yang diretensi tersebut antara lain disebabkan oleh proses pencernaan dan absorbsi zat-zat makanan yang lebih baik sehingga mempercepat laju pakan dalam saluran pencernaan (Mateos et al., 1982). Efisiensi penggunaan protein dari ransum perlakuan menunjukan protein yang tercerna lebih banyak. Hal ini membuktikan bahwa ransum yang menggunakan daun murbei segar sampai pada tingkat pemberian $6 \%$ menunjukan respon positif pada broiler terhadap besaran nitrogen yang diretensi. Retensi nitrogen bernilai positif artinya bahwa tubuh broiler mampu menyerap nitrogen, sehingga broiler tersebut mendapatkan pertambahan bobot badan karena tenunan ototnya bertambah. Retensi nitrogen dipengaruhi oleh beberapa faktor, yaitu :konsumsi ransum, konsumsi protein dan kualitas protein. Semakin tinggi konsumsi ransum, maka retensi nitrogen akan semakin tinggi pula. Menurut Wahju (2004) bahwa meningkatnya konsumsi ransum akan memberikan kesempatan kepada tubuh untuk meretensi lebih banyak makanan sehingga kebutuhan protein untuk pertumbuhan terpenuhi. Retensi nitrogen nyata meningkat dengan meningkatnya protein dalam ransum. Ewing (1963) menyatakan bahwa retensi nitrogen yang menurun dengan adanya peningkatan protein ransum dikarenakan hanya sebagian protein digunakan untuk memenuhi kebutuhan energi. Hal ini menunjukan pentingnya konsumsi energi yang cukup jika ayam digunakan untuk mengevaluasi kualitas protein berdasarkan retensi nitrogen. Wahju (2004) menyatakan bahwa hal yang terpenting pada retensi nitrogen yaitu efisiensi penggunaan protein. Hal tersebut sejalan 
dengan pendapat Parakasi (1990) yang menyatakan bahwa retensi nitrogen akan negatif apabila nitrogen yang dikeluarkan melebihi konsumsi nitrogen, sebaliknya retensi nitrogen akan positif apabila nitrogen yang dikonsumsi lebih tinggi dari pada nitrogen yang dikeluarkan melalui ekskreta.

\section{Pengaruh Perlakuan Terhadap Nilai Energi Metabolis Ransum Broiler}

Nilai energi metabolis dalam penelitian ini merupakan nilai energi metabolis semu yang dikoreksi dengan nilai retensi nitrogen (AMEn). Pada Tabel 3 dapat dilihat bahwa rataan nilai energi metabolis ransum perlakuan berkisar antara 3360,90 - 4023,82 Kkal/kg (Tabel 3). Nilai energi tertinggi diperoleh pada perlakuan R0 (4023,93 $\mathrm{Kkal} / \mathrm{kg})$, selanjutnya diikuti dengan R1 (3517,80 $\mathrm{Kkal} / \mathrm{kg}), \mathrm{R} 2(3451,73 \mathrm{Kkal} / \mathrm{kg})$ dan R3 $(3360,90 \mathrm{Kkal} / \mathrm{kg})$. Hasil penelitian $\mathrm{Al}-$ Kirshi et al (2013) menunjukkan bahwa layer dan broiler menggunakan kira-kira $42 \%$ GE tepung daun murbei. Rata-rata nilai AME tepung daun murbei adalah 7,6 $\mathrm{MJ} / \mathrm{Kg}$ dan AMEn adalah 6,5 MJ/Kg.

$\begin{array}{lcr}\text { Hasil } & \text { analisis } & \text { keragaman } \\ \text { (ANOVA) } & \text { menunjukkan } & \text { bahwa } \\ \text { penggunaan daun murbei segar dalam } & \text { dan } \\ \text { ransum broiler memberikan pengaruh }\end{array}$

berbeda sangat nyata $(\mathrm{P}<0,01)$ terhadap nilai energi metabolis. Hasil uji BNJ menunjukkan bahwa R0 berbeda nyata dengan perlakuan R1, R2 dan R3. Sementara antara perlakuan R1, R2 dan R3 tidak terdapat perbedaan yang nyata. Perlakuan menggunakan daun murbei pada level pemberian $2 \%, 4 \%$ dan $6 \%$ nyata menurun dibandingkan dengan ransum kontrol atau tanpa menggunakan daun murbei (R0).

Menurunnya nilai energi metabolis pada perlakuan menggunakan daun murbei segar diduga disebabkan oleh kandungan serat kasar yang cukup tinggi dalam ransum $(7,99 \%-8,43 \%)$. Serat kasar memiliki sifat meningkatkan laju pakan dalam saluran pencernaan (Bidura, 2007), dengan demikian, penyerapan zat makanan tidak optimal terutama penyerapan sumber energi. Tingginya serat kasar menyebabkan ketersediaan energi dalam ransum yang dikonsumsi menjadi kurang, yang ditandai dengan adanya kecenderungan menurun nilai energi metabolis pada perlakuan $\mathrm{R} 1, \mathrm{R} 2$ dan R3. Bila dilihat dari kandungan energi bruto ransum pada R0 sebesar 4961,93 $\mathrm{Kkal} / \mathrm{kg}$, R1 sebesar 4955,94 Kkal/kg, R2 sebesar 4949,95 Kkal/kg dan R3 sebesar 4943,96 Kkal/kg, dan energi yang dikeluarkan dalam feses maka energi yang 
termetabolis berturut-turut adalah sebagai berikut R0 : 81,09\%, R1 : 70,98\%, R2 : $69,73 \%$ dan R3 : 67,98\%. Hal ini sejalan dengan pendapat Ani et al. (2012) menyatakan bahwa penggunaan pakan berbasis hijauan memberi efek peningkatan serat kasar ransum yang berdampak pada pemanfaatan energi oleh broiler. Namun demikian, jika dilihat dari nilai presentase energi metabolis pada R3 masih cukup tinggi, yang membuktikan bahwa penggunaan daun murbei sampai $6 \%$ masih memberikan respon positif.

\section{KESIMPULAN}

Berdasarkan hasil penelitian ini dapat disimpulkan bahwa daun murbei segar dapat digunakan sebagai salah satu bahan pakan alternatif dalam ransum broiler sampai $6 \%$ dilihat dari nilai retensi nitrogen dan energi metabolis.

\section{DAFTAR PUSTAKA}

Al-Kirshi R. A., A. R Alimoni, A. O Zulkifli, M. W Sasili, I. Sahari. 2013. Nutrient digestibility of Mulbery Leaves (Morus alba). Journal Metrics. Vol 2: 1-4

Ani, A. O., O. D. Omeje and L. C. Ugwuwowo. 2012. Efect of raw bambara nut (Voandzeia subterranea) and apparent nutrion retention in broiler chiken African journal of biotecnology. Vol. 11(56): 11991-11997.

Bidura, I. G. N. 2007. Aplikasi produk bioteknologi pakan ternak. UPT penerbit Universitas Udayana. Denpasar

Ewing, W. R. 1963. Poultry Nutrition. $5^{\text {th }}$ Edition. The Ray Ewing Company Publiser, Pasadena California

Mateos, G. G., J. L Sell and J.A. Eastwood. 1982. Rate of food pesagge (transit time) as influence by level supplemental fat. Poult. Sci.Vol. 61: 94-100.

Nunuh, A. dan O. Andikarya. 2006. Budidaya Sutera Alam (Bomby mori Lin). Politeknik VEDCA Joint Program dengan Politeknik Negeri Jember. Cianjur.

Oku, T., M. Yamada, M. Nakamura, N. Sadamori and S. Nakamura. 2006. Inhibitory effects of extractives from leaves of Morus alba on human and rat small intestinal disaccaridase activity. Journal. Nutr. Vol 95: 933-938.

Parakkasi, A. 1990. Ilmu Gizi dan Makanan Ternak Monogastrik. Cetakan Pertama. Penerbit Angkasa, Bandung.

Rahmi, N. A. 2009. Efek hipoglikemik ekstrak daun murbei (Morus multicaulis) terhadap kadar glukosa darah tikus dm. Tesis. Sekolah Pascasarjana Institut Pertanian Bogor, Bogor. 
Scott, M. L., C. Neisheim and R. J Young. 1982. Nutrition of Chiken. 3rd Edition. Published M. L. Scott and Assosciated: Ithaca. New York.

Steel, R. C. and J. H Torrie. 1995. Prinsip dan Prosedur Statistika. Gramedia Pustaka Utama. Jakarta

Tillman, A. D., H. Hartadi, S. Reksohadiprodjo, S. Prawirokusumo dan S. Lebdosoekojo. 1998. Ilmu Makanan Ternak Dasar. Gadjah Mada University Press. Yogyakarta.

Wahju, J. 2004. Ilmu Nutrisi Unggas. Edisi 4. Gadjah Mada University Press, Yogyakarta

Zarei, A. 2006. Apparent and True Metabolizable Energy in Artemia Meal. International Journal of Poultry Science. Vol 5(7): 627-628 